\title{
The Healthy Built Environments Program: a joint initiative of the NSW Department of Health and the University of NSW
}

\author{
Susan M. Thompson ${ }^{\mathrm{A}, \mathrm{D}}$, Andrew Whitehead $^{\mathrm{B}}$ \\ and Anthony G. Capon ${ }^{\mathrm{A}, \mathrm{C}}$ \\ ${ }^{\mathrm{A}}$ Faculty of the Built Environment, University of New South Wales \\ ${ }^{\mathrm{B}}$ Centre for Health Advancement, NSW Department of Health \\ ${ }^{\mathrm{C}}$ National Centre for Epidemiology and Population Health, \\ The Australian National University \\ ${ }^{\mathrm{D} C o r r e s p o n d i n g ~ a u t h o r . E m a i l: ~ s . t h o m p s o n @ u n s w . e d u . a u ~}$
}

\begin{abstract}
The built environment is increasingly viewed as an important determinant of human health. Consequently creating environments that promote health and wellbeing is one of the NSW Department of Health's key preventive health priorities. This article describes a new program focused on improving health through the quality of the built environment. Recently established in the City Futures Research Centre, Faculty of the Built Environment, University of NSW, the Healthy Built Environments Program receives funding from the NSW Department of Health. The Program will foster cross-disciplinary research, deliver education and workforce development, and advocate for health as a primary consideration in built environment decision making. The Program brings the combined efforts of researchers, educators, practitioners and policymakers from the built environment and health sectors to the prevention of contemporary health problems. The Program's vision is that built environments will be planned, designed, developed and managed in ways that promote and protect the health of all people.
\end{abstract}

In recent years, there has been rising international interest in, and concern about, links between human health, the built environment and ecological sustainability. ${ }^{1-3}$ There is increasing evidence that the physical form of our cities affects health. ${ }^{1-7}$ Neighbourhoods where it is easy to cycle or walk from home to shops and places of employment have been shown to positively contribute to human and environmental health. ${ }^{4-7}$ Conversely, localities that are more spread out, with segregated land uses, disconnected street patterns and limited public transport, are associated with car dependency, less physically active lifestyles of their residents and greater social isolation. ${ }^{4-7}$ These urban forms also contribute to climate change with excessive greenhouse gas emissions created by dependency on cars.

Urban planning has a long association with health. The discipline originated out of concern for human health ${ }^{8}$ and as far back as a century ago was strongly aligned with public health objectives to prevent the spread of disease. Nevertheless, this close relationship between health and urban planning was not sustained as planning moved to focus on urban policy development, design and environmental sustainability, while public health largely pursued a medical model. ${ }^{9}$ Today however, there is a gradual re-alignment of the two as understanding grows of the role that the built environment plays in supporting human health. This paper introduces a recent New South Wales (NSW)-based initiative - the Healthy Built Environments Program (HBEP). Arising from health concerns, the Program is uniquely situated within an urban planning and design context, and will have a strong environmental sustainability focus.

\section{How did we get here?}

At the international level, recognition of the need to embrace a broader understanding of health goes back to the 1970s when the World Health Organization (WHO) commissioned the development of a program of public health reform which today is known as Health21. ${ }^{3,10}$ In 1986 this led to the declaration of the Ottawa Charter for Health Promotion and the establishment of the WHO Healthy Cities Project. In 1992 the United Nation's Agenda21 emerged from its Earth Summit Conference in Rio de Janeiro, Brazil, linking environmental sustainability and human health. ${ }^{3}$ Both Health21 and Agenda21 today underpin the WHO Healthy Cities Project, which links health and sustainable development at the local level. ${ }^{3}$ Healthy Cities Projects in Australia include Onkaparinga (formerly Noarlunga) in South Australia ${ }^{10}$ and the Illawarra in NSW. ${ }^{11}$ 
In Australia, the health sector has led policy initiatives to bridge health and the built environment. Most recently, the Australian Government undertook national reviews of health promotion and the health system more generally. ${ }^{12,13}$ The views of urban planners and designers have informed key recommendations emerging from these reviews. Multiple perspectives have been encouraged in other forums. For example, the Australian Academy of Science 2006 Fenner Conference, Urbanism, Environment and Health, brought together researchers, policymakers, industry and community across a range of disciplines and sectors. ${ }^{14}$ Other significant integrative work includes that of the Victorian Division of the Heart Foundation and its Healthy by Design resource. ${ }^{15}$ In NSW, the Premier's Council for Active Living seeks to strengthen the physical and social environments in which communities engage in active living. ${ }^{16}$ Also in NSW, health impact assessment (HIA) has been identified as a 'key tool for affecting change and to strengthen health input into planning decisions'. ${ }^{17}$

Box 1. Intersectoral partner organisations in the Healthy Built Environments Program

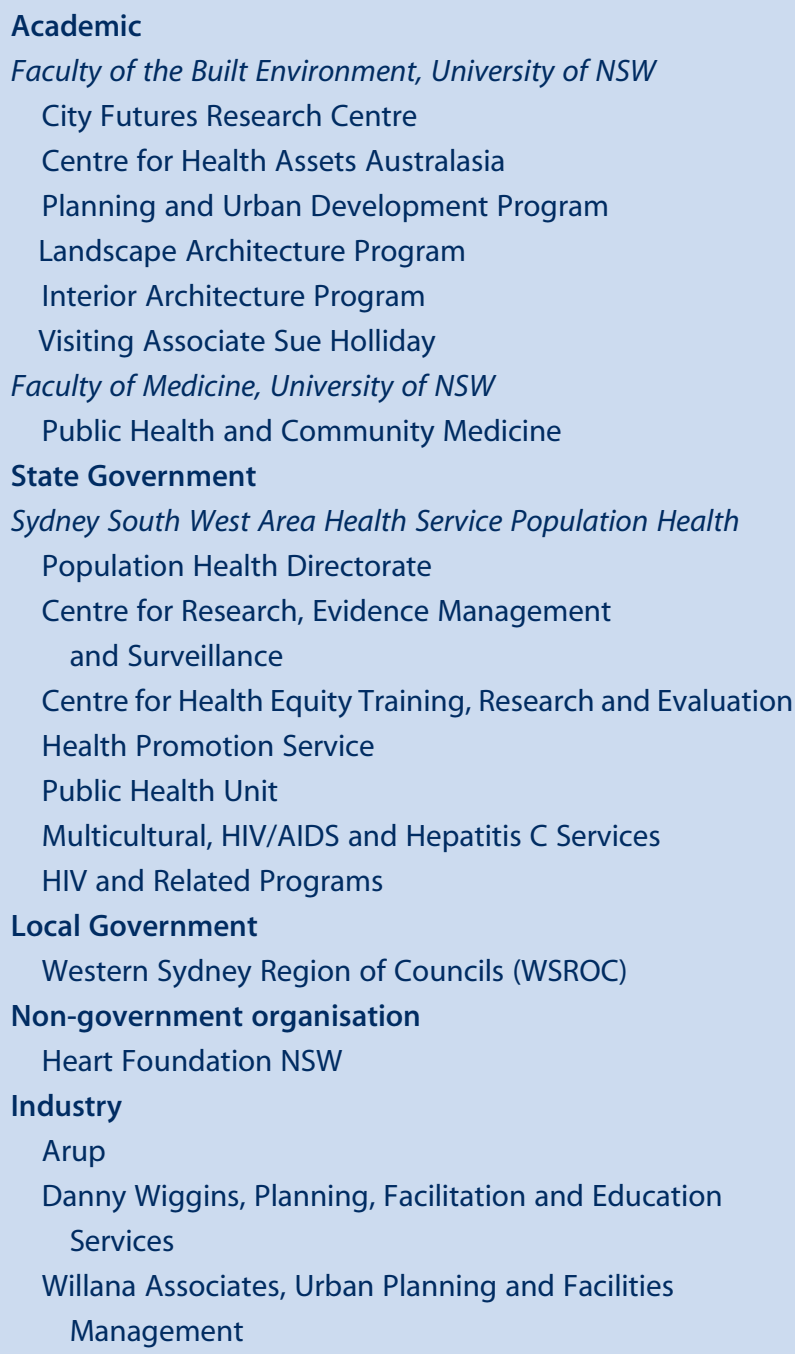

\section{The Healthy Built Environments Program}

With the built environment increasingly viewed as an important determinant of health, creating environments that promote health and wellbeing is one of the NSW Department of Health's preventive health priorities. The importance of preventive health has been identified by the NSW Government in its State Plan, ${ }^{18}$ with further clarification about the role that urban planning plays in relation to human health in the NSW State Health Plan. ${ }^{19}$ While evidence continues to emerge, the NSW Department of Health is aware that more is needed, in particular, information about the impacts of different patterns of urban development on health and the costs and benefits of these impacts.

Consequently, the Department has established the Healthy Built Environments Program at the City Futures Research Centre in the Faculty of the Built Environment at the University of NSW (http://www.fbe.unsw.edu.au/cf/hbep). This 5-year Program will foster interdisciplinary research, deliver innovative education and workforce development, and provide leadership on health and the built environment.

The Program brings together a multidisciplinary team from academic, government, private and non-government organisation (NGO) sectors with expertise across health, urban planning and design, and their inter-relationships (Box 1). The Program is situated in one of Australia's largest faculties of the built environment, which includes all of the design and planning disciplines across scales from individual buildings (their interiors and what is between

Box 2. Healthy Planning: an interdisciplinary educational course of the Healthy Built Environments Program

Healthy Planning is an undergraduate course at the University of NSW. It promotes interdisciplinary approaches as the most effective way to understand the role of the built environment in contemporary health problems. Recent research examining the relationships between the built environment and human health is presented, in the context of a broader perspective on social and environmental sustainability. While there are formal lectures on the latest research and case studies in healthy planning, the principal learning focus is on students working together in interdisciplinary teams. They undertake a detailed neighbourhood audit in which selected urban areas are investigated to determine the level of support for healthy behaviour including physical activity, healthy eating and social interaction. Learning outcomes are focused on interdisciplinary knowledge and practice. The course demonstrates how by working together, cooperatively and with mutual respect and understanding, built environment and health professionals can make a significant contribution to the achievement of healthy cities and societal wellbeing. 
Table 1. The three main areas of focus and the related principal activities of the Healthy Built Environments Program

\begin{tabular}{|c|c|c|}
\hline Focus & Concerns & Major activities \\
\hline Research & $\begin{array}{l}\text { - Interdisciplinarity } \\
\text { - Comprehensiveness } \\
\text { - Policy and practice relevance }\end{array}$ & $\begin{array}{l}\text { - Undertake literature review } \\
\text { - Identify major research gaps } \\
\text { - Determine research strategy with key priorities for NSW } \\
\text { - Synthesis and communication of latest research findings } \\
\text { - Leverage research grants from funding agencies } \\
\text { such as ARC and NHMRC (Box } 3 \text { ) } \\
\text { - Undertake research projects by academics and post } \\
\text { graduate students }\end{array}$ \\
\hline $\begin{array}{l}\text { Workforce development } \\
\text { and education }\end{array}$ & $\begin{array}{l}\text { - Capacity building } \\
\text { - Interdisciplinarity } \\
\text { - Enabling current work force } \\
\text { - Enabling future work force }\end{array}$ & $\begin{array}{l}\text { - Assessment of NSW Health knowledge and skills needs } \\
\text { - Capacity building for NSW Health staff using key tools }{ }^{20,21} \\
\text { and research (e.g. newsletters and website) } \\
\text { - Teach in health and the built environment: } \\
\text { continuation of existing courses and development } \\
\text { of new offerings } \\
\text { - Collaborations between Built Environment and } \\
\text { Medical Faculties }\end{array}$ \\
\hline $\begin{array}{l}\text { Leadership and } \\
\text { advocacy }\end{array}$ & $\begin{array}{l}\text { - Government sector (state and local) } \\
\text { - Private sector } \\
\text { - NGO sector } \\
\text { - Community sector } \\
\text { - Professional organisations }{ }^{\#} \\
\text { representing urban planning, } \\
\text { public health and environmental } \\
\text { health }\end{array}$ & $\begin{array}{l}\text { - Establishment of advisory committee of key } \\
\text { stakeholders across health and built environment } \\
\text { - Participation in community and media events to } \\
\text { promote healthy built environments } \\
\text { - Build on current Faculty work in environmental } \\
\text { sustainability and climate change mitigation } \\
\text { - Seek private sector sponsorship opportunities } \\
\text { with planners, architects and developers } \\
\text { - Build on well established links with relevant } \\
\text { policy makers at state and national levels }\end{array}$ \\
\hline
\end{tabular}

them), through neighbourhoods, to the urban region, city and beyond. The backgrounds of the Program's co-directors Thompson (an urban planner) and Capon (a public health physician) reflect the need for multiple perspectives. Thompson has been leading an undergraduate healthy planning subject since 2007 (Box 2). A new postgraduate course with strong links to the Healthy Built Environments Program has recently been approved by the Faculty's Education Committee.

Positioning the Program within a built environment faculty offers the opportunity to influence the built environment professions and industries to incorporate healthy planning provisions in strategic direction, policy formulation and decision making. With an already established research and educational focus on environmental and social sustainability, the opportunities to develop integrated strategies that bring human health concerns into alignment with environmental issues are considerable.

Table 1 presents the principal activities of the Program across its three main themes: research, workforce development and education, and leadership and advocacy. Box 3 provides two examples of research projects in the Program.

\section{Challenges in moving forward}

There are important potential obstacles to progress on healthy built environments. These include different ways of understanding health, and evidence about health, and the need for effective interdisciplinary collaboration.

Epidemiology is the established method for understanding the distribution of health and disease in populations and 
Box 3. Research projects in the Healthy Built Environments Program

Two health and built environment research projects are currently underway within the Healthy Built Environments Program. The first brings together industry partners NSW Landcom and Heart Foundation, and the Sydney South West Area Health Service. The Australian Research Council (ARC) has funded an investigation into how urban environments support human health. Tracking residents' behaviours over several years, the aim is to identify environmental design features, social interventions and locational qualities in selected neighbourhood sites which positively benefit human health. The research uses a multidisciplinary approach with its team from urban planning, development and health. The second project is funded by the Australian Housing and Urban Research Institute (AHURI). A focussed investigation for one year, it examines the health impacts of housing. The study will identify the current level of knowledge and major research gaps, prioritise these, and propose ways to best explore the highest priority research and policy development needs. An 'Investigative Panel' comprising leading researchers, public health and housing policy officials from across Australasia and New Zealand will be convened to do this.

For further information about these and other projects see the research page of the Healthy Built Environments Program web site: http://www.fbe.unsw.edu.au/cf/hbep/research/

has enabled the identification of many major risks to health. Epidemiology in its current form is however less useful for understanding the complex interplay between multiple biophysical, social and economic factors and the health of people in urban environments. Consequently, it has been argued that epidemiology needs to adopt and develop methods to understand such complexities by drawing insights from ecology. ${ }^{22}$ From the planning perspective, Corburn's 'relational view of place', where he argues for combining laboratory and field site views of urban health, is another methodological model that may be useful in formulating different understandings of health. ${ }^{1}$

A related challenge is to overcome the constraints imposed by disciplinary boundaries and different traditions of evidence. Lawrence ${ }^{23}$ argues for integrative and interdisciplinary approaches in responding to links between the built environment and health. An effective interdisciplinary approach acknowledges individual disciplinary expertise and brings it together with expertise in other disciplines to create new knowledge. The web-based resource, Healthy Spaces and Places, launched last year, is an example of an effective interdisciplinary initiative (Box 4).

\section{Box 4. Healthy Spaces and Places}

Healthy Spaces and Places is a web-based resource that includes practical tools, case studies and guidelines for planning and developing sustainable communities to encourage healthy ways of living. ${ }^{24}$ It is a national initiative of the Planning Institute of Australia, the Australian Local Government Association and the National Heart Foundation, with funding from the Australian Government's Department of Health and Ageing. It is also an excellent demonstration of cross-disciplinary collaboration.

\section{Conclusion}

Interest in the role that environments play in supporting good health, both physical and mental, is high in many countries. In Australia this heightened interest is reflected at national, state and local government levels. Increasingly urban planners and health professionals are working productively together in both strategic policy development and specific service delivery. In order to make progress in climate change mitigation and human physical and mental health improvements, an important challenge will be to shift the way we understand health in the context of built environment and sustainability discourse. The Healthy Built Environments Program, with its interdisciplinary approach, positioned in a faculty of the built environment and with a focus on environmental and social sustainability, is well placed to meet this challenge.

\section{References}

1. Corburn J. Toward the healthy city: People, places, and the politics of urban planning. Cambridge: The MIT Press; 2009.

2. Frumkin H, Frank L, Jackson R. Urban sprawl and public health: designing, planning and building for healthy communities. Washington: Island Press; 2004.

3. Barton H, Tsourou C. Healthy urban planning. London: Spon Press, WHO Regional Office for Europe; 2000.

4. Badland HM, Schofield GM, Garrett N. Travel behaviour and objectively measured urban design variables: associations for adults travelling to work. Health Place 2008; 14(1): 85-95. doi:10.1016/j.healthplace.2007.05.002

5. Garden FL, Jalaludin BB. Impact of urban sprawl on overweight, obesity, and physical activity in Sydney, Australia. J Urban Health 2009; 86(1): 19-30. doi:10.1007/s11524-008-9332-5

6. Frank LD, Saelens BE, Powell KE, Chapman JE. Stepping towards causation: do built environments or neighborhood and travel preferences explain physical activity, driving, and obesity? Soc Sci Med 2007; 65: 1898-914. doi:10.1016/ j.socscimed.2007.05.053

7. Giles-Corti B, Broomhall MH, Knuiman M, Collins C, Douglas K, $\mathrm{Ng} \mathrm{K}$ et al. Increasing walking: how important is distance to, attractiveness, and size of public open space? Am J Prev Med 2005; 28(2, Suppl 2): S169-76. doi:10.1016/j.amepre.2004.10.018 
8. Thompson SM. A planner's perspective on the health impacts of urban settings. N S W Public Health Bull 2007; 18(9-10): 157-60. doi:10.1071/NB07093

9. Botchwey ND, Hobson SE, Dannenberg AL, Mumford KG, Contant CK, McMillan TE et al. A model curriculum for a course on the built environment and public health training for an interdisciplinary workforce. Am J Prev Med 2009; 36(2, Suppl): S63-71. doi:10.1016/j.amepre.2008.10.003

10. Baum F. The New Public Health. Second Edition. South Melbourne: Oxford University Press; 2008.

11. Healthy Cities Illawarra. Available at: http://www.healthycitie sill.org.au/ (Accessed 24 February 2010.)

12. Australian Government Department of Health and Ageing. National Preventative Health Task Force. Available at: http://preventativehealth.org.au/ (Accessed 24 February 2010.)

13. Australian Government House of Representatives, Standing Committee on Health and Ageing. Enquiry into obesity in Australia. Available at: http://www.aph.gov.au/house/committee/ haa/obesity/index.htm (Accessed 24 February 2010.)

14. Capon AG, Dixon JM. Creating healthy, just and eco-sensitive cities. N S W Public Health Bull 2007; 18: 37-40. doi:10.1071/ NB07065

15. National Heart Foundation of Australia (Victorian Division) Healthy by design: a planners' guide to environments for active living. Melbourne: National Heart Foundation of Australia (Victorian Division); 2004.
16. NSW Government. Premier's Council for Active Living. Available at: http://www.pcal.nsw.gov.au/ (Accessed 24 February 2010.)

17. Thackway SV, Milat AJ, Develin E. Influencing urban environments for health: NSW Health's response. N S W Public Health Bull 2007; 18: 150-1. doi:10.1071/NB07105

18. NSW Government. State Plan: a new direction for NSW. Sydney: Premier's Department; 2006.

19. NSW Department of Health. State Health Plan towards 2010 : a new direction for NSW. North Sydney: NSW Department of Health; 2007.

20. NSW Department of Health. Healthy Urban Development Checklist. North Sydney: NSW Department of Health; 2009. Available at: http://www.health.nsw.gov.au/pubs/2010/ hud_checklist.html (Accessed 24 February 2010.)

21. Premier's Council for Active Living. Development and Active Living: Designing Projects for Active Living. Sydney: NSW Premier's Council for Active Living; 2010.

22. March D, Susser E. The eco- in eco-epidemiology. Int $J$ Epidemiol 2006; 35(6): 1379-83. doi:10.1093/ije/dyl249

23. Lawrence RJ. Housing and health: from interdisciplinary principles to transdisciplinary research and practice. Futures 2004; 36(4): 487-502. doi:10.1016/j.futures.2003.10.001

24. Healthy Spaces and Places. Available at: www.healthyplaces. org.au (Accessed 24 February 2010.) 